\title{
23. Sr, Nd, AND Pb ISOTOPE GEOCHEMISTRY OF THE UPPER AND LOWER VOLCANIC SERIES AT SITE $642^{1}$
}

\author{
Paul N. Taylor ${ }^{2}$ and Andrew C. Morton ${ }^{3}$
}

\begin{abstract}
ODP Leg 104 recovered $914 \mathrm{~m}$ of volcanics at Site 642 on the Vøring Plateau in the Norwegian Sea. The upper series of these volcanics correlates with seaward-dipping seismic reflectors (DRS), and is tholeiitic in character. The lower series underlies the DRS and is broadly andesitic in character. $\mathrm{Rb}-\mathrm{Sr}, \mathrm{Sm}-\mathrm{Nd}$, and $\mathrm{Pb}$ isotopic analyses show that upper series samples have isotopic features characteristic of MORB, except for one dike sample that has a $\mathrm{Pb}$ isotopic composition that may indicate interaction of its parent magma with older continental crust. The five most silicic samples from the lower series, which occur high up in the sequence, define a $63 \pm 19 \mathrm{Ma} \mathrm{Rb}-\mathrm{Sr}$ whole-rock isochron age, and have an initial ${ }^{87} \mathrm{Sr} /{ }^{86} \mathrm{Sr}$ of $0.7116 \pm 0.0004$. Other lower series samples have lower initial ${ }^{87} \mathrm{Sr} /{ }^{86} \mathrm{Sr}$, but all are greater than any upper series rock. The combined evidence of initial ${ }^{87} \mathrm{Sr} /{ }^{86} \mathrm{Sr}$, initial $\epsilon_{\mathrm{Nd}}$ values, Sm-Nd model ages, $\mathrm{Pb}$ isotopic compositions, and petrographic features clearly indicate that lower series rocks were derived, at least in part, from continental crustal source materials. That the DRS is underlain by rocks of continental character is an important observation, constraining models for the development of DRS-type passive continental margins.
\end{abstract}

\section{INTRODUCTION}

The main objectives in drilling Site 642 during ODP Leg 104 were to determine the composition and nature of a sequence of seaward-dipping seismic reflectors and to ascertain the nature of the basement to this dipping reflector series (DRS). The drill site is located on the outer Vøring Plateau in the eastern Norwegian Sea. DRS are now known to be characteristic of many passive continental margins, but they are often covered by thick sedimentary sequences, and they are therefore usually inaccessible to drilling. However, on the outer Vøring Plateau only a few hundred meters of sediment cover the DRS, so that Site 642 represents an ideal locality at which to investigate the nature and mode of origin of passive continental margins characterised by DRS structures (Eldholm, Thiede, Taylor, et al., 1987a).

At Site 642, JOIDES Resolution recovered $315 \mathrm{~m}$ of mainly pelagic and hemipelagic Miocene or younger sediments, and below the sediments a 914-m sequence including volcanic flows, volcaniclastic sediment layers, and a few dikes. The volcanic sequence may be divided into a tholeiitic upper series, and an andesitic lower series. The location of Site 642 landward of magnetic anomaly 24B implies that the volcanics are of early Eocene age or older. For the lower series, that indication is substantially confirmed by paleontological evidence in the interlayered sediments (mainly palynomorphs), which also suggests an early Eocene age (Boulter and Manum, this volume; Manum et al., this volume). The lower series is considered to have been erupted under water, while the upper series was probably erupted mostly in a sub-aerial environment, but with some sub-aqueous flows (Eldholm, Thiede, Taylor, et al., 1987a).

An important conclusion of Eldholm, Thiede, Taylor, et al. (1987b) is that the dipping reflector sequence can confidently be correlated with the upper volcanic series of alternating massive, fine-grained, and highly vesicular medium-grained tholeitic

\footnotetext{
${ }^{1}$ Eldholm, O., Thiede, J., Taylor, E., et al., 1989. Proc. ODP, Sci. Results, 104: College Station, TX (Ocean Drilling Program).

2 Department of Earth Sciences, Parks Road, Oxford OX1 3PR, United Kingdom.

${ }^{3}$ British Geological Survey, Keyworth, Nottingham NG12 5GG, United King-
}

flows. Thus, the lower volcanic series is identified as the basement immediately underlying the DRS.

The lower series consists of andesitic flows, shallow-level dikes, and volcaniclastic sediments of intermediate to felsic composition. Xenolithic fragments in the sediments include abundant mica, feldspar, and quartz, and more rarely, quartz-mica schist and leucocratic gneiss: there is no doubt as to the continental origins of this material. Grading in a 5-m-thick ignimbrite unit in the series indicates a proximal source. Eldholm, Thiede, Taylor, et al. (1987b) conclude that the country rock at the eruption center, close to Site 642 , was probably continental crust.

\section{SAMPLE SELECTION}

Samples for radiogenic isotope geochemistry have been selected from the suites of the upper and lower volcanic series analyzed for major and trace elements and rare-earth element compositions by Viereck et al. (this volume) and Parson et al. (this volume). Details of the location of each analyzed sample are given in Table 1, together with the rock unit to which the sample is assigned in the initial report on Site 642 (Eldholm, Thiede, Taylor, et al., 1987a); i.e., flows, designated F, and dikes, designated D, are numbered consecutively down Hole 642E. All 27 samples selected for isotopic study have been analyzed for $\mathrm{Sr}$ isotopic composition (analytical data in Table 1). Sm-Nd isotopic analyses have been made on five upper series and on three lower series samples (Table 2), and eleven upper series samples and seven lower series samples have been analyzed for $\mathrm{Pb}$ isotopic composition (Table 3).

\section{ANALYTICAL METHODS}

Generally, the analytical methods for determining the $\mathrm{Sr}, \mathrm{Pb}$, and $\mathrm{Nd}$ isotopic compositions follow well-established procedures. However, to diminish the effects of seawater alteration on the $\mathrm{Sr}$ isotopic composition of the volcanics from Site 642 we have resorted to a pretreatment of the sample powders by leaching them in hot 6- $\mathrm{M} \mathrm{HCl}$ prior to digestion in $\mathrm{HF}$ and nitric acid. The hot $6-\mathrm{M} \mathrm{HCl}$ is used to remove easily soluble $\mathrm{Sr}$, much of which is probably associated with alteration products. In a similar study on volcanics recovered from the Rockall Trough (Morton et al., 1988), the procedure had the effect of lowering ${ }^{87} \mathrm{Sr} /{ }^{86} \mathrm{Sr}$ ratios in rocks with ${ }^{87} \mathrm{Sr} /{ }^{86} \mathrm{Sr}$ ratios less than the value of 0.709 characteristic of modern seawater, and raising the ${ }^{87} \mathrm{Sr} /{ }^{86} \mathrm{Sr}$ ratios in rocks with ${ }^{87} \mathrm{Sr} /{ }^{86} \mathrm{Sr}$ ratios greater than 0.709 . The procedure is thus effective in restoring the $\mathrm{Sr}$ isotopic composition to a value closer to the (igneous) initial ratio. 
Table 1. Rb-Sr isotopic analyses of Leg 104, Hole 642E igneous rocks.

\begin{tabular}{|c|c|c|c|c|c|c|c|c|}
\hline \multirow{2}{*}{$\begin{array}{l}\text { Lab } \\
\text { no. }\end{array}$} & \multirow{2}{*}{$\begin{array}{l}\text { Rock } \\
\text { unit }\end{array}$} & \multirow{2}{*}{$\begin{array}{l}\text { Core no., } \\
\text { position }\end{array}$} & \multirow[b]{2}{*}{$\mathrm{SiO}_{2} \%$} & \multirow{2}{*}{$\begin{array}{c}\mathrm{Rb} \\
\mathrm{ppm}\end{array}$} & \multirow{2}{*}{$\begin{array}{c}\mathrm{Sr} \\
\mathrm{ppm}\end{array}$} & \multirow[b]{2}{*}{${ }^{87} \mathrm{Rb} /{ }^{86} \mathrm{Sr}$} & \multicolumn{2}{|c|}{${ }^{87} \mathrm{Sr} /{ }^{86} \mathrm{Sr}$} \\
\hline & & & & & & & Present & at $60 \mathrm{Ma}$ \\
\hline \multicolumn{9}{|c|}{ Upper Series } \\
\hline 1 & D1 & $9-1,66-68$ & 47.9 & 2 & 146 & 0.0396 & 0.70332 & 0.70329 \\
\hline 4 & F7 & $13-1,102-104$ & 49.2 & 3 & 174 & 0.0497 & 0.70365 & 0.70361 \\
\hline 5 & F11 & $15-3,61-63$ & 48.5 & 2 & 169 & 0.0341 & 0.70318 & 0.70315 \\
\hline 7 & F17 & $18-4,96-98$ & 48.5 & 2 & 179 & 0.0324 & 0.70326 & 0.70323 \\
\hline 11 & F29 & $28-2,30-31$ & 49.4 & 0.9 & 160 & 0.0162 & 0.70313 & 0.70312 \\
\hline 14 & F36 & $30-3,135-137$ & 49.6 & 2 & 185 & 0.0312 & 0.70325 & 0.70322 \\
\hline 15 & F45 & $37-2,31-33$ & 49.3 & 3 & 194 & 0.0448 & 0.70313 & 0.70309 \\
\hline 17 & F53 & $46-3,61-63$ & 50.1 & 2 & 182 & 0.0318 & 0.70325 & 0.70322 \\
\hline 19 & F59 & $55-1,43-45$ & 49.3 & $2 *$ & 184 & 0.0314 & 0.70330 & 0.70327 \\
\hline 21 & F67 & $64-4,71-73$ & 49.3 & 16 & 166 & 0.2788 & 0.70389 & 0.70365 \\
\hline 22 & F72 & $66-1,82-84$ & 48.7 & 1 & 191 & 0.0150 & 0.70327 & 0.70326 \\
\hline 26 & F87 & $76-2,14-16$ & 49.1 & 2 & 176 & 0.0330 & 0.70316 & 0.70313 \\
\hline 30 & F94 & $81-1,68-70$ & 49.1 & $3^{*}$ & 196 & 0.0443 & 0.70336 & 0.70332 \\
\hline 31 & F95 & $83-1,42-44$ & 49.0 & 6 & 172 & 0.1009 & 0.70397 & 0.70388 \\
\hline 32 & F98 & $86-1,86-88$ & 48.8 & 2 & 155 & 0.0373 & 0.70359 & 0.70356 \\
\hline 36 & F103 & $90-2,73-75$ & 48.5 & 1 & 127 & 0.0229 & 0.70313 & 0.70311 \\
\hline 38 & F105 & $94-1,65-67$ & 49.1 & 1 & 119 & 0.0243 & 0.70326 & 0.70324 \\
\hline \multicolumn{9}{|c|}{ Lower Series } \\
\hline $39+$ & F107 & $97-1,133-135$ & 59.9 & 61 & 119 & 1.4838 & 0.71292 & 0.71166 \\
\hline $40+$ & F108 & $98-1,60-62$ & 61.1 & 86 & 143 & 1.7409 & 0.71300 & 0.71152 \\
\hline $42+$ & D4 & $101-1,109-111$ & 64.5 & 76 & 187 & 1.1764 & 0.71263 & 0.71163 \\
\hline $45+$ & F116 & $102-2,4-6$ & 61.9 & 99 & 183 & 1.5661 & 0.71309 & 0.71176 \\
\hline 46 & D5 & $104-1,18-20$ & 51.8 & 3 & 65 & 0.1336 & 0.70523 & 0.70512 \\
\hline $47+$ & F117 & $106-1,86-88$ & 60.0 & 57 & 213 & 0.7746 & 0.71225 & 0.71159 \\
\hline 48 & D6 & $107-2,82-84$ & 49.4 & 8 & 107 & 0.2163 & 0.70664 & 0.70646 \\
\hline 49 & F119 & $109-1,17-20$ & 49.5 & 30 & 160 & 0.5426 & 0.70947 & 0.70901 \\
\hline 50 & F121 & $109-2,90-92$ & 55.5 & 81 & 158 & 1.4839 & 0.71097 & 0.70971 \\
\hline 51 & D7 & $110-1,44-46$ & 51.9 & 41 & 136 & 0.8725 & 0.70958 & 0.70884 \\
\hline
\end{tabular}

Rock units are those designated by Eldholm, Thiede, Taylor, et al. (1987) in the description of the core recovered from Hole $642 \mathrm{E}: \mathrm{D}=$ dike, $\mathrm{F}=$ flow.

$\mathrm{SiO}_{2} \%, \mathrm{Rb}$, and $\mathrm{Sr}$ concentrations determined by XRF at the University of Newcastle (Analyst: P. J. Oakley) except for $\mathrm{Rb}$ analyses marked by ${ }^{*}$, which were determined by atomic absorption. ${ }^{87} \mathrm{Rb} /{ }^{86} \mathrm{Sr}$ ratios were determined from the XRF concentration data. Samples marked + were used in the construction of the $\mathrm{Rb}-\mathrm{Sr}$ isochron for the lower series; they are the most silicic samples analyzed. Present ${ }^{87} \mathrm{Sr} /{ }^{86} \mathrm{Sr}$ ratios are determined to a precision of \pm 0.00004 ( 2 sigma error). The age correction for the upper series samples is very small, and does not add greatly to the uncertainty on the initial ratios, but for some lower series samples the magnitude of the correction is greater, so that uncertainties on the age for initial ratio calculation, and on the ${ }^{87} \mathrm{Rb} /$

${ }^{86} \mathrm{Sr}$ ratio may affect the error on the initial ratio significantly.

Table 2. Sm-Nd isotopic analyses of Leg 104, Hole 642E igneous rocks.

\begin{tabular}{|c|c|c|c|c|c|c|c|}
\hline \multirow{2}{*}{$\begin{array}{l}\text { Lab. } \\
\text { No. }\end{array}$} & \multirow{2}{*}{$\begin{array}{l}\text { Rock } \\
\text { Unit }\end{array}$} & \multirow{2}{*}{$\begin{array}{c}\mathrm{Sm} \\
\mathrm{ppm}\end{array}$} & \multirow{2}{*}{$\begin{array}{l}\mathrm{Nd} \\
\mathrm{ppm}\end{array}$} & \multirow[b]{2}{*}{${ }^{147} \mathrm{Sm} /{ }^{144} \mathrm{Nd}$} & \multirow[b]{2}{*}{${ }^{143} \mathrm{Nd} /{ }^{144} \mathrm{Nd}$} & \multicolumn{2}{|c|}{$\epsilon_{\mathrm{Nd}}$} \\
\hline & & & & & & Present & $60 \mathrm{Ma} \mathrm{BP}$ \\
\hline \multicolumn{8}{|c|}{ Upper Series } \\
\hline 1 & D1 & 3.283 & 10.393 & 0.1909 & 0.513044 & 7.9 & 8.0 \\
\hline 7 & F17 & $3.16^{*}$ & $9.89^{*}$ & 0.193 & 0.513056 & 8.2 & 8.2 \\
\hline 15 & F45 & $4.60^{*}$ & $17.6^{*}$ & 0.158 & 0.513013 & 7.3 & 7.6 \\
\hline 30 & F94 & $4.34^{*}$ & $16.0^{*}$ & 0.164 & 0.513026 & 7.6 & 7.S \\
\hline 32 & F98 & $4.51^{*}$ & $16.6^{*}$ & 0.164 & 0.512926 & 5.6 & 5.9 \\
\hline \multicolumn{8}{|c|}{ Lower Series } \\
\hline $39+$ & F107 & 5.895 & 26.798 & 0.1330 & 0.512178 & -9.0 & -8.5 \\
\hline 46 & D5 & 2.671 & 7.376 & 0.2189 & 0.512723 & 1.7 & 1.5 \\
\hline 50 & F121 & 6.581 & 27.857 & 0.1428 & 0.512262 & -7.3 & -6.9 \\
\hline
\end{tabular}

Rock units are those designated by Eldholm, Thiede, Taylor, et al. (1987) in the description of the core recovered from Hole 642E: $D=$ dike, $F=$ flow.

$\mathrm{Sm}$ and $\mathrm{Nd}$ concentrations determined by mass spectrometric isotope dilution, except analyses marked *, which were determined by neutron activation at the Imperial College Reactor Centre (Analyst: I. Sinclair). ${ }^{147} \mathrm{Sm} /{ }^{144} \mathrm{Nd}$ ratios were determined from the Sm and Nd concentration data. Uncertainties on the present ${ }^{143} \mathrm{Nd} /{ }^{144} \mathrm{Nd}$ ratios are between \pm 0.000020 and \pm 0.000025 ( 2 sigma errors). 
Table 3. Pb isotopic analyses of Leg 104 , Hole $642 \mathrm{E}$ igneous rocks.

\begin{tabular}{lllll}
\hline Lab. & Rock & ${ }^{206} \mathrm{~Pb} /{ }^{204} \mathrm{~Pb}$ & ${ }^{207} \mathrm{~Pb} /{ }^{204} \mathrm{~Pb}$ & ${ }^{208} \mathrm{~Pb} /{ }^{204} \mathrm{~Pb}$ \\
No. & Unit
\end{tabular}

Upper Series

$\begin{array}{lllll}1 & \text { D1 } & 17.459 & 15.515 & 37.311 \\ 4 & \text { F7 } & 18.433 & 15.536 & 38.324 \\ 7 & \text { F17 } & 18.289 & 15.519 & 38.059 \\ 15 & \text { F45 } & 18.323 & 15.510 & 38.097 \\ 19 & \text { F59 } & 18.344 & 15.519 & 38.151 \\ 21 & \text { F67 } & 18.463 & 15.544 & 38.370 \\ 30 & \text { F94 } & 18.279 & 15.532 & 38.136 \\ 31 & \text { F95 } & 18.329 & 15.510 & 38.174 \\ 32 & \text { F98 } & 18.460 & 15.562 & 38.460 \\ 36 & \text { F103 } & 18.231 & 15.510 & 38.082 \\ 38 & \text { F105 } & 18.293 & 15.528 & 38.187\end{array}$

Lower Series

$\begin{array}{lllll}39 & \text { F107 } & 18.710 & 15.604 & 38.770 \\ 45 & \text { F116 } & 18.697 & 15.587 & 38.724 \\ 46 & \text { D5 } & 18.509 & 15.571 & 38.513 \\ 48 & \text { D6 } & 18.605 & 15.568 & 38.602 \\ 49 & \text { F119 } & 18.662 & 15.561 & 38.629 \\ 50 & \text { F121 } & 18.690 & 15.585 & 38.728 \\ \text { 51 } & \text { D7 } & 18.674 & 15.582 & 38.687\end{array}$

Rock units are those designated by Eldholm, Thiede, Taylor, et al. (1987) in the description of the core recovered from Hole 642E: $\mathrm{D}=$ dike, $\mathrm{F}=$ flow.

$\mathrm{Pb}$ isotopic analyses have been corrected for mass fractionation of $-0.125 \%$ per a.m.u., assessed from frequent analyse of the NBS SRM $981 \mathrm{~Pb}$ isotope standard. Uncertainties on the $\mathrm{Pb}$ isotopic analyses are estimated as ca. $0.1 \%$ on the reported ratios.

Sr samples for mass spectrometric analysis were prepared using conventional cation exchange column procedures. $\mathrm{Sr}$ samples were loaded on single tantalum filaments with phosphoric acid, and analyzed on a VG Isomass 54E fully automated mass spectrometer using a single Faraday cup collector. ${ }^{87} \mathrm{Sr} /{ }^{86} \mathrm{Sr}$ ratios have been normalized to a value of 8.37521 for the ${ }^{88} \mathrm{Sr} /{ }^{86} \mathrm{Sr}$ ratio. Eimer \& Amend $\mathrm{Sr}$ isotope standard analysis, used several times during the course of this work, gave a value of $0.70799 \pm 0.00003$ for the ${ }^{87} \mathrm{Sr} /{ }^{86} \mathrm{Sr}$ ratio.

Samples for Sm-Nd isotopic analysis were decomposed in $\mathrm{HF}$ and nitric acid in autoclave bombs, then evaporated to dryness, dissolved in $3 \mathrm{M} \mathrm{HCl}$, and the REE separated as a group by cation exchange in $3 \mathrm{M}$ $\mathrm{HCl}$. Nd (and Sm) were separated from the other REE by sequential elution in $\mathrm{HCl}$ on reversed-phase chromatographic columns containing HDEHP supported on teflon powder. For four samples, Sm and Nd concentrations were determined by mass spectrometric isotope dilution using a mixed tracer solution enriched in ${ }^{149} \mathrm{Sm}$ and ${ }^{150} \mathrm{Nd}$. Nd isotopic compositions for these four samples were determined on the spiked $\mathrm{Nd}$ samples. Sm and Nd were loaded on Ta side filaments of a triple filament assembly, with $\mathrm{Re}$ center filaments. The analyses were all performed on a VG Isomass 54E instrument, as described above. Nd isotopic analyses are normalized to a value of 0.7219 for the unspiked ratio of ${ }^{146} \mathrm{Nd} /{ }^{144} \mathrm{Nd}$. Determinations of the ${ }^{143} \mathrm{Nd} /{ }^{144} \mathrm{Nd}$ ratio in the USGS standard basalt, BCR-1, average $0.512634 \pm 0.000020$ on this instrument.

Samples for $\mathrm{Pb}$ isotopic analysis were prepared using anion exchange columns, by loading the samples in $1 \mathrm{M} \mathrm{HBr}$ solution, washing the columns with $1 \mathrm{M} \mathrm{HBr}$, and then eluting $\mathrm{Pb}$ with $6 \mathrm{M} \mathrm{HCl}$. $\mathrm{Pb}$ samples were loaded on single Re filaments with silica gel and phosphoric acid, and analyzed on a VG Isomass 54E instrument.

Isochron fitting was carried out using the method of York (1969). The following values of the decay constants were used for age calculations and age correction of present isotopic ratios to initial values: $\lambda^{87} \mathrm{Rb} \times 10^{-11} \mathrm{yr}^{-1} ; \lambda^{147} \mathrm{Sm}, 6.54 \times 10^{-12} \mathrm{yr}^{-1}$. For the calculation of $\epsilon_{\mathrm{Sr}}$ and $\epsilon_{\mathrm{Nd}}$ values the following present day bulk earth isotopic ratios were assumed:

$$
{ }^{87} \mathrm{Sr} /{ }^{86} \mathrm{Sr}=0.7047 ;{ }^{87} \mathrm{Rb} /{ }^{86} \mathrm{Sr}=0.0847 ;{ }^{143} \mathrm{Nd} /{ }^{144} \mathrm{Nd}=0.512638 ;
$$

and

$$
{ }^{147} \mathrm{Sm} /{ }^{144} \mathrm{Nd}=0.1966 .
$$

Sm-Nd T-DM model ages are calculated using DePaolo's (1981) empirical equation for the Nd isotopic evolution of the depleted mantle.

\section{THE UPPER VOLCANIC SERIES}

\section{Rb-Sr Isotope Data}

$\mathrm{Rb}-\mathrm{Sr}$ isotope data are reported in Table 1 for 17 samples of the upper volcanic series. Rb concentrations of $3 \mathrm{ppm}$ or less are an almost ubiquitous feature of this series (Viereck et al., this volume) and ${ }^{87} \mathrm{Rb} /{ }^{86} \mathrm{Sr}$ ratios correspondingly low, with values typically less than 0.05 . Two samples (F67 and F95) differ from this general pattern, having Rb concentrations of 16 and 6 ppm, and ${ }^{87} \mathrm{Rb} /{ }^{86} \mathrm{Sr}$ ratios of ca. 0.28 and 0.10 , respectively. $\mathrm{Sr}$ concentrations in the analyzed upper series rocks range from ca. $120 \mathrm{ppm}$ up to ca. $200 \mathrm{ppm}$ (Viereck et al., this volume). Present day ${ }^{87} \mathrm{Sr} /{ }^{86} \mathrm{Sr}$ ratios, measured after leaching with hot $6 \mathrm{M} \mathrm{HC1}$ (see above), range from 0.70313 up to 0.70397 , but most samples cluster towards the lower end of that range. For most upper series samples (not F67 and F95) the magnitude of the correction for radiogenic Sr generated since eruption is smaller than the analytical uncertainties on the measured ${ }^{87} \mathrm{Sr} /{ }^{86} \mathrm{Sr}$ ratios, for eruption ages up to ca. $60 \mathrm{Ma}$ (see Table 1). Initial ${ }^{87} \mathrm{Sr} /{ }^{86} \mathrm{Sr}$ ratios, calculated assuming an age of $60 \mathrm{Ma}$, range from 0.70309 $(\mathrm{F} 45)$ to $0.703 \mathrm{~S} 8$ (F95). These ratios translate into $\epsilon \mathrm{Sr}$ values between -22 and -11 , thus indicating derivation of the upper series volcanics from a source with an integrated history of depletion in $\mathrm{Rb}$ relative to $\mathrm{Sr}$ compared to bulk earth $\mathrm{Rb}-\mathrm{Sr}$ characteristics.

Several hypotheses might be advanced to account for the variations in apparent initial ${ }^{87} \mathrm{Sr} /{ }^{86} \mathrm{Sr}$ ratios in the upper series volcanics: (a) $\mathrm{Sr}$ isotopic heterogeneity in the source of the parent magmas of upper series volcanics, (b) variable contamination of parent magmas by interaction with isotopically distinct country rocks during ascent from source or ponding in magma chambers, (c) variable degrees of alteration by interaction with seawater, and ineffectiveness of the pretreatment of samples prior to $\mathrm{Sr}$ separation for isotopic analysis.

To some extent these rival hypotheses can be tested using isotopic data determined for other radioactive decay schemes, in particular $\mathrm{Sm}-\mathrm{Nd}$ and $\mathrm{U}-\mathrm{Th}-\mathrm{Pb}$. In the event that the source heterogeneity hypothesis (a) is appropriate, covariations in $\mathrm{Sr}$ and $\mathrm{Nd}$ isotopic composition might be expected, within the mantle array on the (Nd) vs. ( $\mathrm{Sr}$ ) diagram. For hypothesis (b), in the $(\mathrm{Nd})$ vs. (Sr) diagram, contamination might cause variations coincident with the mantle array. For hypothesis (c), however, seawater alteration is expected to shift data points for affected samples out to the right of the mantle array in $\epsilon_{\mathrm{Nd}} \mathrm{vs} . \epsilon_{\mathrm{S} r}$ as the $\mathrm{Nd}$ concentration in seawater is so low that modification of $\mathrm{Nd}$ isotopic composition by seawater alteration can only take place given very high water/rock ratios.

\section{Sm-Nd Isotope Data}

Sm-Nd data for five upper series volcanic rocks are presented in Table 2. Sm concentrations range from ca. 3.2 to $4.6 \mathrm{ppm}$; Nd concentrations from ca. 9.9 to $17.6 \mathrm{ppm} .{ }^{147} \mathrm{Sm} /{ }^{144} \mathrm{Nd}$ ratios in samples D1 and F17 are close to chondritic values (0.191 and 0.193 , respectively), whereas ${ }^{147} \mathrm{Sm} /{ }^{144} \mathrm{Nd}$ ratios of ca. 0.16 for F45, F94, and F98, are characteristic of slightly LREE-enriched materials. However, there is little variation in Nd isotopic composition within the analyzed upper series samples (present ${ }^{143} \mathrm{Nd}$ / ${ }^{144} \mathrm{Nd}$ ratios from 0.512926 to 0.513056 ), so that the variations in REE chemistry between the samples cannot be very long- 
lived. Present $\epsilon_{\mathrm{Nd}}$ values are from 5.6 to $8.2 ; \epsilon_{\mathrm{Nd}}$ values at $60 \mathrm{Ma}$ are from 5.9 to 8.2 . This indicates that all five samples are derived from sources with an integrated history of LREE depletion relative to bulk earth.

$\epsilon_{\mathrm{Nd}}$ data are plotted against the corresponding $\epsilon_{\mathrm{Sr}}$ values (all corrected to $60 \mathrm{Ma}$ ) for upper (and lower) series samples in Figure 1 . The upper series samples all plot within the mantle array (not shown in Fig. 1) defined by a large body of $\mathrm{Nd}$ and $\mathrm{Sr}$ isotopic data on MORB and ocean island basalts (OIB), so that it is unlikely that seawater alteration can account for the $\mathrm{Sr}$ isotopic compositional variations, at least among the five samples for which paired $\mathrm{Sr}$ and $\mathrm{Nd}$ isotopic data exist. Thus hypothesis (c) is probably excluded, but no clear resolution between hypotheses (a) and (b) can yet be made.

\section{Pb Isotope Data}

$\mathrm{Pb}$ isotopic compositions of eleven upper series samples are presented in Table 3 and Figures $2 \mathrm{~A}$ and $2 \mathrm{~B}$, together with data for the lower series volcanics. Figure $2 \mathrm{~A}$ is the plot of ${ }^{208} \mathrm{~Pb} /$ ${ }^{204} \mathrm{~Pb}$ vs. ${ }^{206} \mathrm{~Pb} /{ }^{204} \mathrm{~Pb}$, and Figure $2 \mathrm{~B}$ is the ${ }^{207} \mathrm{~Pb} /{ }^{204} \mathrm{~Pb}$ vs. ${ }^{206} \mathrm{~Pb} /{ }^{204} \mathrm{~Pb}$ diagram. In both plots, the lower end of the field of $\mathrm{Pb}$ isotopic compositions found in fresh modern North Atlantic mid-ocean ridge basalts (NAMORB) is shown for comparison (data from Cohen et al., 1980; Dupré and Allègre, 1980). With one exception, all the upper series volcanics plot inside or within analytical error of the NAMORB compositional envelope in both diagrams.

Sample D1, tentatively interpreted as a fine-grained basic dike emplaced near the top of the upper volcanic series (Eldholm, Thiede, Taylor, et al., 1987a), is the exception, with a $\mathrm{Pb}$ isotopic composition, markedly less radiogenic than other samples at Site 642 :

$$
{ }^{206} \mathrm{~Pb} /{ }^{204} \mathrm{~Pb} 17.459 ;{ }^{207} \mathrm{~Pb} /{ }^{204} \mathrm{~Pb} 15.515 ;{ }^{208} \mathrm{~Pb} /{ }^{204} \mathrm{~Pb}=37.311
$$

Indeed, in the ${ }^{207} \mathrm{~Pb} /{ }^{204} \mathrm{~Pb}$ vs. ${ }^{206} \mathrm{~Pb} /{ }^{204} \mathrm{~Pb}$ diagram, $\mathrm{D} 1$ plots to the left of the geochron, indicating $\mathrm{Pb}$ isotopic evolution retarded relative to bulk earth. In basaltic rocks of oceanic affinities this is an unusual feature, but it is better known in those emplaced in continental environments. The characteristic may derive either from source material which was once part of sub-

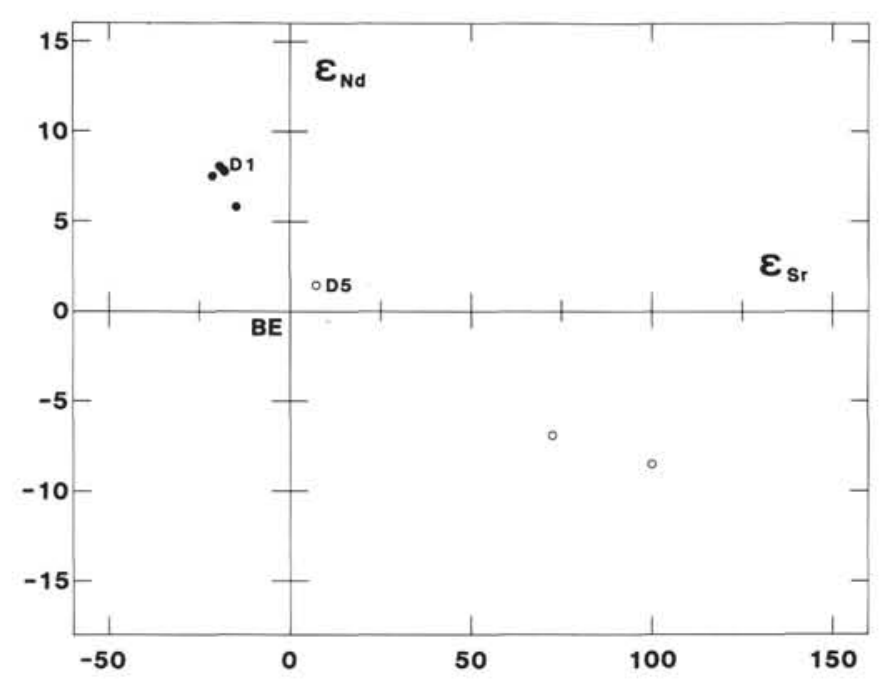

Figure 1. A plot of $\epsilon_{\mathrm{Nd}}$ vs. $\epsilon_{\mathrm{Sr}}$ values of upper series (open circles) and lower series (filled circles) igneous rocks recovered from ODP Site 642 on the outer Vøring Plateau. BE represents the composition of the bulk earth. continental lithospheric mantle, or by contamination with old U-depleted continental crustal material. However, it is important to note that neither the Rb-Sr nor the Sm-Nd data for this sample are in any way distinctive in comparison with other upper series samples: $\mathrm{Rb}-\mathrm{Sr}$ and $\mathrm{Sm}-\mathrm{Nd}$ isotopic compositions for D1 are, in fact, almost indistinguishable from the data for F17. This suggests that the $\mathrm{Pb}$ isotopic composition is probably not a feature of the source of the parent magma of D1, but may have been derived by some process of selective $\mathrm{Pb}$ extraction from country rock material during magma ascent and/or ponding in a magma chamber: seawater alteration is unlikely to produce any significant effect on the $\mathrm{Pb}$ isotopic composition of the basalts because, like $\mathrm{Nd}, \mathrm{Pb}$ is only present at very low concentrations in seawater (ca. $2 \mathrm{pg} / \mathrm{g}$ ).

\section{THE LOWER VOLCANIC SERIES}

\section{Rb-Sr Isotope Data}

Table 1 presents $\mathrm{Rb}-\mathrm{Sr}$ isotopic analyses for 10 lower series samples, which show a much greater compositional diversity than the analyzed Upper Series rocks. Rb concentrations vary between 3 and 100 ppm; Sr varies between 65 and 215 ppm (Parson et al., this volume). There is a large range of ${ }^{87} \mathrm{Rb} /{ }^{86} \mathrm{Sr}$ ratios, from 0.13 to 1.74 , and a range of present-day ${ }^{87} \mathrm{Sr} /{ }^{86} \mathrm{Sr}$ ratios from 0.70523 to 0.71309 , all higher than any of the values measured on upper series samples. The most radiogenic $\mathrm{Sr}$ isotopic compositions are generally found in the upper units of the lower volcanic series: these same units are generally the most silicic recovered at Site 642 , with silica ranging from ca. 60 to $64.5 \%$ (see also Fig. 4). Data for these units (five samples) are plotted in a Rb-Sr isochron diagram (Fig. 3), and define an isochron line (MSWD 2.02), which yields a date of $63 \pm 19 \mathrm{Ma}$, and an initial ${ }^{87} \mathrm{Sr} /{ }^{86} \mathrm{Sr}$ ratio of $0.71157 \pm 0.00038$ ( 2 sigma errors). The result is not very precise and is also open to some question because the ${ }^{87} \mathrm{Rb} /{ }^{86} \mathrm{Sr}$ ratios are based on total $\mathrm{Sr}$ concentrations in the samples, whereas the ${ }^{87} \mathrm{Sr} /{ }^{86} \mathrm{Sr}$ ratios are measured after acid leaching to remove unknown quantities of $\mathrm{Sr}$ introduced by alteration processes. However, the date is in reasonable accord with the palaeontological indications of an early Eocene age for the lower series (Boulter and Manum, this volume; Manum et al., this volume), and this suggests that the leaching procedure has not seriously biased the isochron date. (The effects of leaching procedures on the Rb-Sr systematics of samples recovered at Site 642 are discussed further by LeHuray in this volume.) For further discussion of isotopic data on the lower series volcanics, an age of $60 \mathrm{Ma}$ has been assumed in calculating the correction for radiogenic development of $\mathrm{Sr}$ and $\mathrm{Nd}$ since eruption.

Figure 4 is a plot of ${ }^{87} \mathrm{Sr} /{ }^{86} \mathrm{Sr}$ at $60 \mathrm{Ma}$ vs. percent $\mathrm{SiO}_{2}$, for both upper and lower volcanic series. Upper series rocks form a tight cluster in the bottom left-hand corner of the diagram, with $\mathrm{SiO}_{2}$ ranging from ca. $48 \%$ to $50 \%$ and ${ }^{87} \mathrm{Sr} /{ }^{86} \mathrm{Sr}(60 \mathrm{Ma})<0.704$. By contrast, the lower series includes volcanics with between $49.5 \%$ and $64.5 \%$ silica, and with ${ }^{87} \mathrm{Sr} /{ }^{86} \mathrm{Sr}(60 \mathrm{Ma})$ from 0.70512 to 0.71176 . The high silica volcanics $\left(\mathrm{SiO}_{2}>60 \%\right)$ form one coherent grouping, all clearly derived from sources with similar histories of $\mathrm{Rb}-\mathrm{Sr}$ fractionation, and having $\epsilon_{\mathrm{Sr}}$ values very close to +100 at $60 \mathrm{Ma}$. On the basis of petrographic observations (Eldholm, Thiede, Taylor, et al., 1987a), there is little doubt that these rocks are derived from continental crustal source material (see also Introduction above).

F119, F121, and D7 are the deepest rock units recovered at Site 642 which have been analyzed in this study. They have lower silica contents than the upper units of the lower series, respectively $49.5 \%, 55.5 \%$, and $51.9 \%$, and they also have lower ${ }^{87} \mathrm{Sr} /$ ${ }^{86} \mathrm{Sr}$ (60 Ma) ratios; 0.70901, 0.70957, and 0.70884. However, they differ from two dike samples (D5 and D6) which also have 

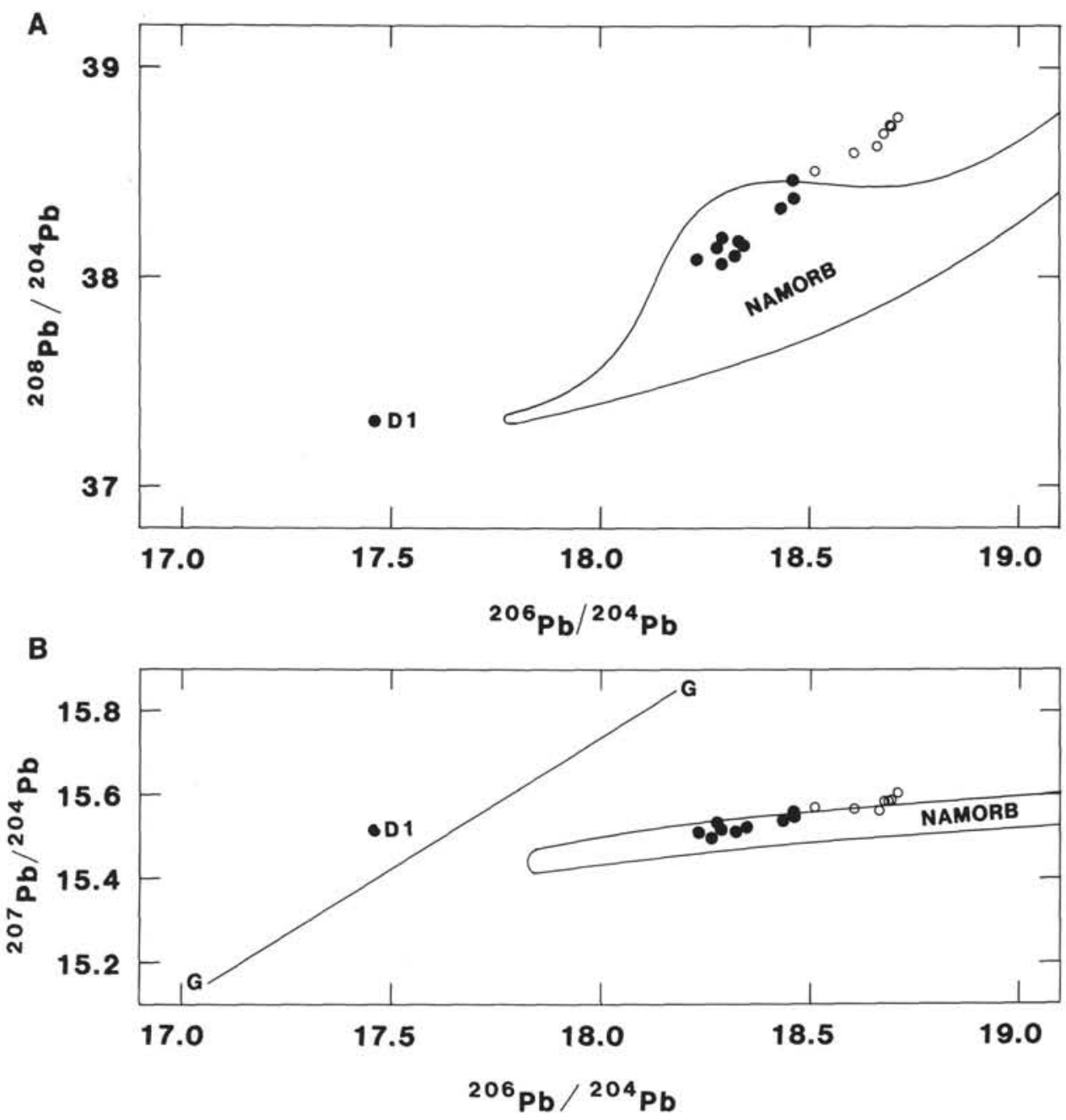

Figure 2. (A) plot of ${ }^{208} \mathrm{~Pb} /{ }^{204} \mathrm{~Pb}$ vs. ${ }^{206} \mathrm{~Pb} /{ }^{204} \mathrm{~Pb}$ for upper and lower series igneous rocks from Site 642 . Symbols as in figure 1. The NAMORB field is based on data for North Atlantic Mid-Ocean Ridge Basalts presented by Cohen et al. (1980), and Dupré and Allègre (1980). (B) plot of ${ }^{207} \mathrm{~Pb} /{ }^{204} \mathrm{~Pb}$ vs. ${ }^{206 \mathrm{~Pb}} /{ }^{204} \mathrm{~Pb}$ for upper and lower series igneous rocks from Site 642. Symbols as in figure 1. The NAMORB field is defined as for (A) above. The line GG represents the geochron.

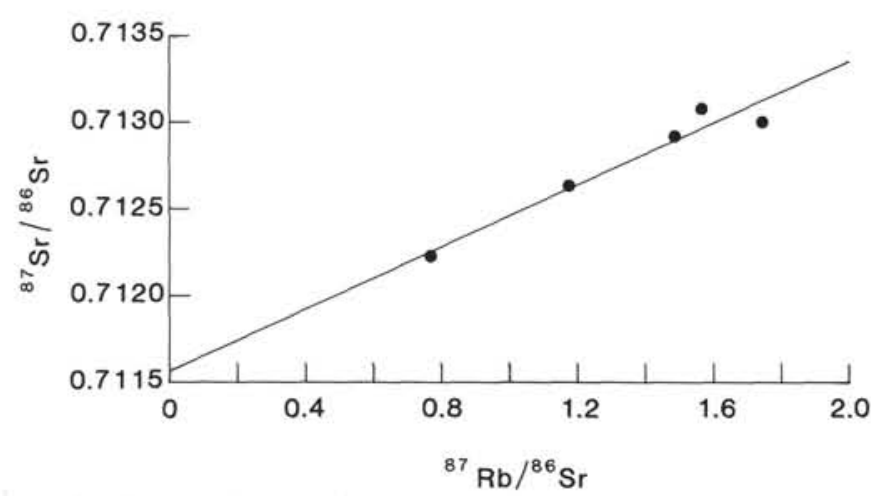

Figure 3. Rb-Sr whole-rock isochron diagram for the five most silicic lower series flows. The best-fit isochron (MSWD 2.02) yields an age of $63 \pm 19 \mathrm{Ma}$, and an initial ${ }^{87} \mathrm{Sr} /{ }^{86} \mathrm{Sr}$ of $0.7116 \pm 0.0004(2$ sigma errors). low silica ( $51.8 \%$ and $49.4 \%$, respectively). Samples from D5 and D6 have Rb concentrations of $3 \mathrm{ppm}$ and $8 \mathrm{ppm}$, respectively, whereas samples F119, F121, and D7 have between 30 and $80 \mathrm{ppm} \mathrm{Rb}$ ). The $\mathrm{Sr}$ isotopic composition of D5 and D6 have the lowest ${ }^{87} \mathrm{Sr} /{ }^{86} \mathrm{Sr}$ ratios measured in the lower series, with values of 0.70512 and 0.70646 at $60 \mathrm{Ma}$. However, all the analyzed lower volcanic series samples have positive values of $\epsilon_{\mathrm{Sr}}$ at $60 \mathrm{Ma}$, indicating that they have all been derived from sources with an integrated history of $\mathrm{Rb}$ enrichment over $\mathrm{Sr}$ relative to the bulk earth characteristics.

\section{Sm-Nd Isotope Data}

Sm-Nd isotopic analyses have been determined for three lower series samples, one each from the upper group of high silica volcanics, the lowest group of low silica, high Rb volcanics, and the low silica, low Rb dikes (Table 2). F107 and F121 have low ${ }^{147} \mathrm{Sm} /{ }^{144} \mathrm{Nd}$ ratios of 0.1334 and 0.1446 , indicating LREE-enriched character, whereas D5 has a ${ }^{147} \mathrm{Sm} /{ }^{144} \mathrm{Nd}$ ratio of 0.2216 , greater than the chondritic value and indicating a LREE-depleted character. $\epsilon_{\mathrm{Nd}}$ values for F107 and F121 at $60 \mathrm{Ma}$ are -8.5 and -6.9 , respectively, whereas D5 has an $\epsilon_{\mathrm{Nd}}$ value of +1.5 . Thus, F107 and F121 have been derived from a source with a history of long-term LREE enrichment relative to bulk 


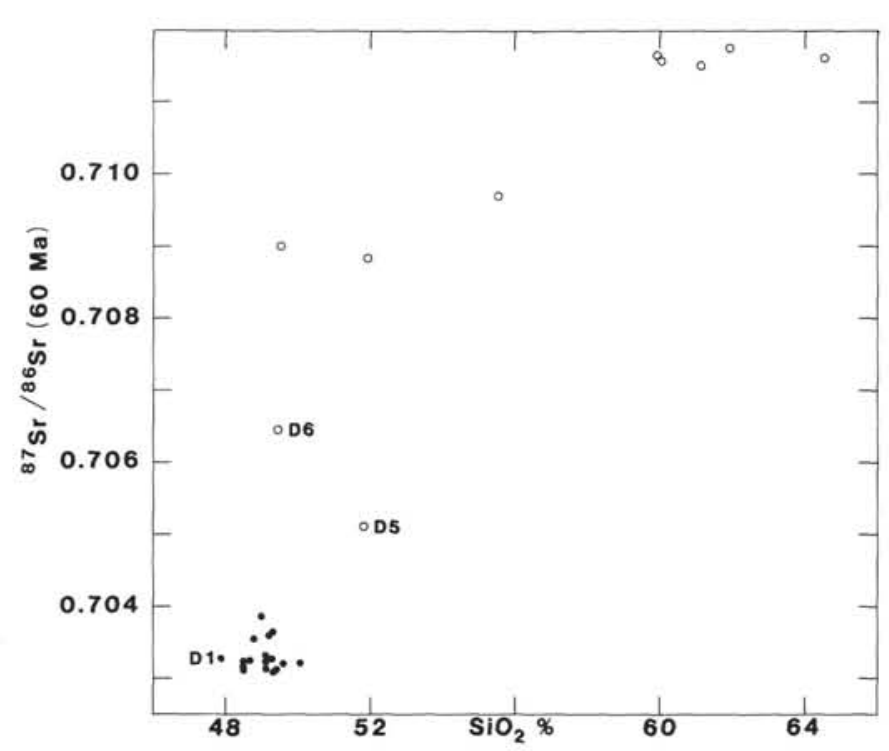

Figure 4. A plot of initial ${ }^{87} \mathrm{Sr} /{ }^{86} \mathrm{Sr}$ (calculated at $60 \mathrm{Ma}$ ) vs. silica percentage for upper and lower series igneous rocks from Site 642. Symbols as in Figure 1.

earth. F109 and F121 have T-CHUR model ages (DePaolo and Wasserburg, 1976) of 1.10 and $1.06 \mathrm{Ga}$, or T-DM model ages (DePaolo, 1981) of 1.62 and $1.67 \mathrm{Ga}$, respectively. Thus LREE enrichment has been a characteristic of the source of these volcanics since at least as long ago as mid-Proterozoic times. By contrast, the positive $\epsilon_{\mathrm{Nd}}$ value for D5 indicates its derivation from a source with an integrated history of LREE depletion relative to bulk earth.

$\epsilon_{\mathrm{Nd}}$ values are plotted against $\epsilon_{\mathrm{Sr}}$ values for the lower series rocks in Figure 1. F107 and F121 plot in the lower right-hand quadrant, together with the oldest continental crustal material (but not high-grade gneisses which suffered severe Rb depletion early in their crustal residence history). The upper right-hand quadrant position of D5 is somewhat unusual with both $\epsilon_{\mathrm{Nd}}$ and $\epsilon_{\mathrm{Sr}}$ having positive values. In many magmatic processes it can be shown that $\mathrm{Rb} / \mathrm{Sr}$ and $\mathrm{Nd} / \mathrm{Sm}$ fractionate coherently, so that it is difficult to envisage how a single source can develop characteristics of clear LREE-depletion coupled with enrichment of $\mathrm{Rb}$ relative to $\mathrm{Sr}$. The $\mathrm{Rb}-\mathrm{Sr}$ and $\mathrm{Sm}-\mathrm{Nd}$ isotopic characteristics of D5 might therefore be explained better as the product of mixing of $\mathrm{Sr}$ and $\mathrm{Nd}$ derived from two sources, one in the depleted mantle quadrant (upper left), and the other in the quadrant typical of most continental crustal material (lower right). Mixing trends between endmembers in such locations might then pass to the right of bulk earth (BE in Fig. 1), intersecting the upper right-hand quadrant. The interpretation of the $\epsilon_{\mathrm{Nd}}$ and $\epsilon_{\mathrm{Sr}}$ data for this sample is that the dike represents a magma derived from a depleted mantle source, but modified by interaction with materials of continental origins. In Figure 1 it is evident that magmas with original characteristics like those of the upper volcanic series rocks could become like D5 by interaction with lower series material similar to F107 and F121. That hypothesis is examined in light of lower series $\mathrm{Pb}$ isotope data described below.

\section{Pb Isotope Data}

$\mathrm{Pb}$ isotopic analyses are presented in Table 3 for seven lower series samples. The data are also presented in the diagrams of ${ }^{208} \mathrm{~Pb} /{ }^{204} \mathrm{~Pb}$ and ${ }^{207} \mathrm{~Pb} /{ }^{204} \mathrm{~Pb}$ vs. ${ }^{206} \mathrm{~Pb} /{ }^{204} \mathrm{~Pb}$ in Figures $2 \mathrm{~A}$ and $2 \mathrm{~B}$. In both diagrams the lower series volcanics are clearly separated from the upper series: the lower series rocks all have slightly more radiogenic $\mathrm{Pb}$ isotopic compositions. In Figure $2 \mathrm{~A}$, all lower series samples fall outside the envelope enclosing NAMORB $\mathrm{Pb}$ isotopic compositions, but in Figure 2B most of the lower series samples plot within the analytical error of the upper bound of the NAMORB field. While the average ${ }^{206} \mathrm{~Pb}$ / ${ }^{204} \mathrm{~Pb}$ and ${ }^{208} \mathrm{~Pb} /{ }^{204} \mathrm{~Pb}$ ratios of the lower series rocks are close to estimates of modern average continental $\mathrm{Pb}$ (ca. 18.70 and 38.63, respectively), ${ }^{207} \mathrm{~Pb} /{ }^{204} \mathrm{~Pb}$ is lower than average continental $\mathrm{Pb}$ (ca. 15.63) (Stacey and Kramers, 1975). In view of the clear indications from $\mathrm{Rb}-\mathrm{Sr}$ and $\mathrm{Sm}-\mathrm{Nd}$ data of continental provenance for much of the lower series material, it is somewhat unexpected that the $\mathrm{Pb}$ isotope data should, in this case, fail to give any clear indication of continental origins for these rocks.

The two dikes $\mathrm{D} 5$ and $\mathrm{D} 6$ have the least radiogenic $\mathrm{Pb}$ isotopic compositions among the analyzed lower series volcanics, and plot closest to the upper series compositions in Figures 2A and 2B. Lower series data (Fig. 5) define a smooth trend from samples with the most radiogenic $\mathrm{Sr}$ and $\mathrm{Pb}$ isotopic compositions (the high silica volcanic group) through the more basic volcanics, and continuing through the two dike samples, D5 and D6, toward the cluster of upper series analyses. Like the trend in the $\epsilon_{\mathrm{Nd}}$ vs. $\epsilon_{\mathrm{Sr}}$ diagram (Fig. 1) described above, the trend in Figure 5 also suggests that D5 and D6 may be the product of interaction between magmas derived from a mantle source similar to that of the upper series volcanics and other lower series rocks, which constitute the country rock into which these dikes have been emplaced.

\section{DISCUSSION}

\section{Origins of the Upper Volcanic Series}

The combined $\mathrm{Sr}, \mathrm{Nd}$, and $\mathrm{Pb}$ isotopic characteristics of most of the analyzed upper series samples are closely similar to NAMORB. $\mathrm{Sr}$ and $\mathrm{Nd}$ isotopic compositions plot within the mantle array in the $\epsilon_{\mathrm{Nd}}$ vs. $\epsilon_{\mathrm{Sr}}$ diagram, at positions a bit closer to $\mathrm{BE}$ than most NAMORB, reflecting derivation from mantle source material slightly less depleted than typical MORB-source mantle. $\mathrm{Pb}$ isotopic compositions plot entirely within the fields defined by NAMORB. Thus, the interpretation of the upper se-

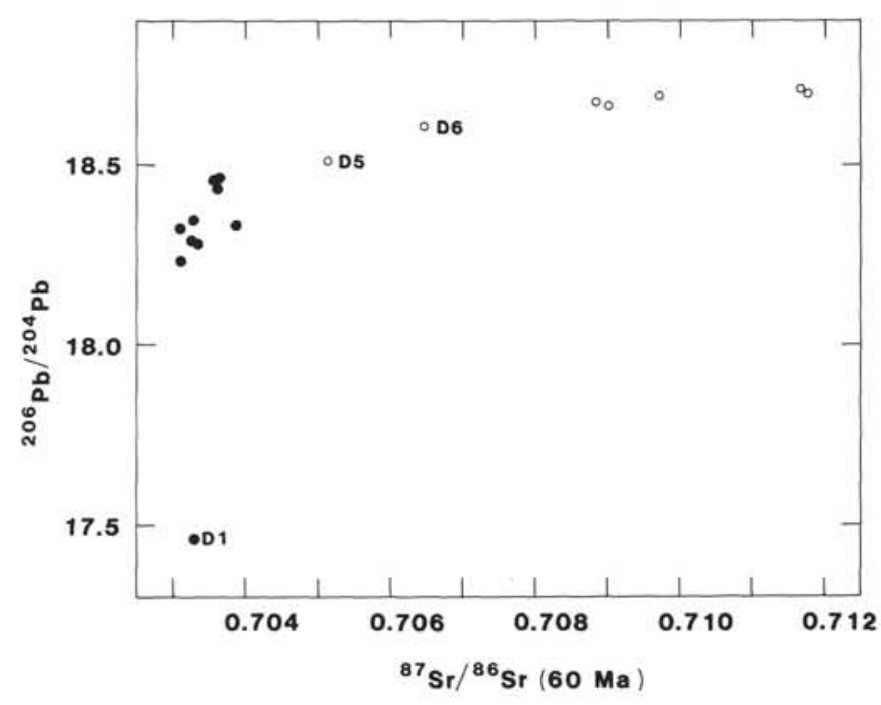

Figure 5. A plot of ${ }^{206} \mathrm{~Pb} /{ }^{204} \mathrm{~Pb}$ vs. initial ${ }^{87} \mathrm{Sr} /{ }^{86} \mathrm{Sr}$ ratio for upper and lower series igneous rocks from Site 642. Symbols as in Figure 1. (No correction has been applied to the present-day $\mathrm{Pb}$ isotopic compositions for $60 \mathrm{Ma}$ of in situ U-decay.) 
ries as representing some of the first out-pourings of MORBtype basalts associated with the opening of the Norwegian Sea would seem to be appropriate.

However, there are a few anomalies in the radiogenic isotope data for the upper series which hint strongly at an unusual basement to this basalt sequence. A few of the analyzed basalts have unusually high potash contents (F67 and F95), with $0.61 \%$ and $0.42 \%$, respectively (Viereck et al., this volume), and also have higher initial ${ }^{87} \mathrm{Sr} /{ }^{86} \mathrm{Sr}$ ratios $(0.70365$ and 0.70388$)$ than most of the other upper series rocks. The explanation for these anomalies is not entirely clear, but possibilities include derivation from source material less depleted than that of other upper series basalts, contamination by interaction of parent magmas with basement material, or extensive alteration by hydrothermal interaction with seawater. The dike $\mathrm{D} 1$, with its distinctive $\mathrm{Pb}$ isotopic composition, markedly less radiogenic than any other upper series sample, or (indeed) any NAMORB, also suggests continental basement at Site 642 as a source of contaminant $\mathrm{Pb}$ for the parent magma of the dike.

\section{Origins of the Lower Volcanic Series}

The silicic compositions (Parson et al., this volume) and high initial ${ }^{87} \mathrm{Sr} /{ }^{86} \mathrm{Sr}$ ratios of most lower series samples, combined with the negative $\epsilon_{\mathrm{Nd}}$ values and mid-Proterozoic Sm-Nd model ages for F107 and F121, provide a strong case for the derivation of these rocks from continental crustal source material. The isotopic characteristics of the two basic dikes, D5 and D6, suggest that the parent magmas of these rocks were derived from a mantle source, possibly similar to that of the upper volcanic series, and were then modified by interaction with material of crustal derivation, probably the other lower series rocks into which the dikes were emplaced.

\section{Structure of DRS-type Passive Continental Margins}

At Site 642 it is now well established that the DRS consists of basaltic rocks with MORB-like characteristics, but with a few anomalies probably resulting from the tectonic setting at the edge of the continent. It has also been established that the DRS is underlain by more silicic volcanic rocks, erupted only slightly prior to the onset of MORB-type magmatism, but clearly derived from source material of very different character than that of MORB. The lower series volcanics clearly have continental origins, from consideration not only of their radiogenic isotope characteristics, but also of their petrography (Eldholm, Thiede, Taylor, et al., 1987a). Furthermore, Hole 642E is considered to be quite close to the site of eruption of these continentally-derived volcanics (Eldholm, Thiede, Taylor, et al., 1987b). Thus, a penecontemporaneously formed silicic basement to the DRS has been directly proved by drilling at Site 642 , but deeper, older continental basement can be inferred in the radiogenic isotope evidence.

\section{ACKNOWLEDGMENTS}

We thank Roy Goodwin, Douglas Foster, and Clive Johnson for skilled technical assistance with $\mathrm{Sr}$ and $\mathrm{Pb}$ analyses, and John Arden for preparing Sm and Nd samples. P. J. Oakley and I. Sinclair kindly made available their major- and trace-element analyses of the Site 642 upper and lower volcanic series. We thank Matthew Thirwall and Anne LeHuray for their careful reviews and constructive comments on an earlier draft of this paper. We gratefully acknowledge financial support for this project from the Institute of Oceanographic Sciences, and we thank Dr. Lindsay Parson for his encouragement and help in making this project possible. We are also grateful to Dr. Stephen Moorbath for the use of the facilities of the Geological Age and Isotope Research Laboratory at Oxford. This paper is published with the approval of the Director, British Geological Survey (N.E.R.C.).

\section{REFERENCES}

Cohen, R. S., Evensen N. M., Hamilton P. J., and O'Nions, R. K., 1980. U-Pb, Sm-Nd and $\mathrm{Rb}-\mathrm{Sr}$ systematics of mid-ocean ridge basalt glasses. Nature, 283: 149-153.

DePaolo, D. J., 1981. Neodymium isotopes in the Colorado Front Range and crust-mantle evolution in the Proterozoic. Nature, 291:193-196.

DePaolo, D. J., and Wasserburg, G. J., 1976. Inferences about magma sources and mantle structure from variations of ${ }^{143} \mathrm{Nd} /{ }^{144} \mathrm{Nd}$. Geophys. Res. Lett., 3:743-746.

Dupré, B., and Allègre, C. J., 1980. Pb-Sr-Nd isotopic correlation and the chemistry of North Atlantic mantle. Nature, 286:17-22.

Eldholm, O., Thiede, J., Taylor, E., et al., 1987a. Proc. ODP, Init. Repts., 104: College Station, TX (Ocean Drilling Program).

Eldholm, O., Thiede, J., Taylor, E., et al., 1987b. Summary and Preliminary conclusions, ODP Leg 104. In Eldholm, O., Thiede, J., Taylor, E., et al., Proc. ODP Init. Repts., 104: College Station (Ocean Drilling Program), 751-771.

Morton, A. C., Dixon, J. E., Fitton, J. G., MacIntyre, R. M., Smythe, D. K., and Taylor, P. N., 1988. Early Tertiary volcanic rocks in well 163/6-1A, Rockall Trough. Spec. Publ., Geol. Soc. London, 39: 293-308.

Stacey, J. S., and Kramers, J. D., 1975: Approximation of terrestrial lead isotope evolution by a two-stage model. Earth Planet. Sci. Lett., 26:207-221

York, D., 1969. Least squares fitting of a straight line with correlated errors. Earth Planet. Sci. Lett., 5:320-324.

Date of initial receipt: 27 July 1987

Date of acceptance: 7 November 1988

Ms 104B-133 